\title{
Secure Between God and Man: Peace, Tranquility and Sexuality through the Pietistic Aspirations of Believing Women
}

\author{
Mariam B. Khan \\ dr.mariam.b.khan@gmail.com
}

Fatima Seedat

fatima.seedat@uct.ac.za

\begin{abstract}
This paper draws on a qualitative case study of the intersections of gender, religion and sexual and reproductive health and rights of Muslim wives on the east coast of South Africa. Under analysis are the ways in which women negotiate personal and domestic conflicts of married life guided by the religious aspiration to please God and secure a place in Heaven. This is achieved in part through pleasing their husband through sexual availability regardless of personal desire and, in their view, thereby ensuring a peaceful home. While their negotiations in the home expand our ideas of peace-making, their sexual choices through the course of peace-making raise ethical concerns on consent and mutuality. Taking up Kecia Ali's argument for a 'just ethics of sexual intimacy' alongside Saba Mahmood's analysis of pietistic agency and African feminist analysis of the place of domestic peace in human security, the paper highlights the interplay of choice and obligation in the negotiation of the pietistic aspiration of peace and tranquillity in the home.
\end{abstract}

Keywords: Peace, Piety, Women, Sexual agency, South Africa, Tabligh Jamāa $a t$ 


\section{Mariam B. Khan \& Fatima Seedat}

\section{Introduction}

Security debates, which originate in international relations, have historically drawn a wide distance between security on the battle front and security on the home front. Feminist theorists however, have breached the distance between the two extending the definition of security to include domestic security (Sjoberg \& Martin 2007: 9; Seedat 2016: 1), and instead, argued for recognition of a 'continuum of violence against women' (Lewis 2013: 16; Seedat 2016: 1), thus connecting war time violence to domestic violence too. Statistics in South Africa indicate exacerbated levels of intimate partner violence which confirm feminist arguments that women experience heightened threats to their security in personal relationships, sufficient to warrant urgent attention and focused resources to ensure their collective security (Boonzaier 2005). While the scholarship is still emerging, recent research exploring the connection between religion and women's security indicate that marriage, sexuality and dynamics of the family unit feature strongly amongst women's security concerns (Seedat 2016; Khan 2016; Petersen 2016).

In line with these developments, this paper explores the ethics of choice and obligation in the ways in which Muslim women negotiate between sexual availability and earning God's pleasure. The conversations that inform this paper arise out of a study in an active Muslim community on the east coast of South Africa ${ }^{1}$. The study was directed by a phenomenological research design, using both phenomenological and feminist critical theoretical frameworks to capture the lived experiences of women negotiating their reproductive concerns through their pietistic commitments. Through an interview and a personal narrative written by each woman, the study examined common shared essences (Patton 2002: 106). While the research examined how women made contraceptive choices, the interviews indicated that contraceptive choices were viewed in terms of the practical considerations of health and were unrelated to piety. Instead, women's sexual choices, namely the decision to have sex regardless of sexual desire, were significantly determined by their pietistic commitments. Accordingly, this paper focuses on the sexual negotiations of believing women aspiring toward a peaceful home and the pleasure of God.

${ }^{1}$ Referring to Master's Dissertation titled 'Negotiating between health-based contraceptive concerns and piety: The experiences of Muslim wives in the Greater Durban Area'. See Reference: Khan, M.B. 2015. 


\section{The Ethics of Sexual Availability, Family, and Peace in the Home}

Ideas of peace develop from values such as love, justice, safety and mutual respect (Lazarus \& Taylor 1999: 92). Ideas of ethics being intimately entrenched in ideas of right and wrong, or the justifications and authority for an action (Pera \& van Tonder 2005: 4), it may seem natural that an ethics of peace, peace-making and conflict resolution is operative in ensuring the peaceful state of a home. Contextualising peace, equally, indicates different meaning for different people. In conflict areas peace may mean periods of no war, to aggressive people peace may mean 'exercising control and restraint over our power to hurt', to a person facing personal moral conflicts peace may translate as inner peace as indicated in the sexual negotiations of the women in the study below (Lazarus \& Taylor 1999: 93).

The decisions around having sex and maintaining a peaceful home environment come together in popular Muslim teachings on family and married life. The communal focus of Islamic teachings makes the family, whether nuclear or extended, the central atomic unit of Muslim society (Omran 1992: 13-14; Dhami \& Sheikh 2000: 352; Bahar, Okcay, Ozbicakci, Beser, Ustun \& Ozturk 2005: 559). Marriage (and sex), though not obligatory, are anticipated life phases for most Muslims (Ali 2006: 6; Christopher 2006: 194) and more so since premarital or extramarital sex is strictly forbidden (Bowen 1981: 326; Christopher 2006: 194; Srikanthan \& Reid 2008: 132). Sex, however, is not only acknowledged for procreation and sexual satisfaction (Shaikh 2003: 114; Christopher 2006: 194), it is also equated to 'an act of worship that is deserving of Allah's reward' (Dhami \& Sheikh 2000: 353).

Sharī'ah, often loosely termed as Islamic Law, does not entail the structured codification synonymous with Western Law (Brockopp 2008: 8). Instead it is inclusive of a system of laws and ethics, the first legally enforceable under ideal conditions, the second enforceable mostly through the workings of one's conscience and the force of social convention. With the closest Arabic term equivalent to ethics translating to 'moral' or 'character', Kecia Ali argues that 'the relationship between enforceable duties and ethical obligations has become increasingly blurred' (Ali 2006: xxi-xxii). Subsequently she questions the operations of Islamic jurisprudence in addressing concerns of marriage, family and sex (Ali 2006: xxii). Ali argues instead for a departure from the patriarchal classical legal opinions on sex and 


\section{Mariam B. Khan \& Fatima Seedat}

sexuality toward the evolutionary aspect of the Islamic faith and Islamic jurisprudence to promote the emergence of a 'just ethics of sexual intimacy', one that is inclusive of 'meaningful consent and mutuality' holding value to both men and women (Ali 2006: 151).

Interpretation of the verses relating to marriage in the Qur'an reinforces the social nature of Islamic teachings by promoting Islamic marriage as a space of tranquillity within which qualities of love and mercy exist (Omran 1992: 13-14). However, the classical Islamic law of marriage, premised upon a marriage of dominion where a wife contracts herself to sexual availability to her husband in exchange for which a husband is under obligation for maintenance of his wife and their joint household, problematizes the ways in which this tranquility may be achieved (Ali 2006: 3-6). Kecia Ali highlights ahadith popularly cited to imply earning God's pleasure is dependent upon and directly related to pleasing one's husband, which is largely understood as sexual availability (Ali 2006: 10-12). The permissibility of a husband to forcefully gain sexual access, she clarifies, is a Hanafi perspective that is considered unethical, albeit lawful (Ali 2006: 12).

How is this consistent with an Islamic doctrine of moral consciousness aimed at peace and tranquillity? Ali's argument for an evolutionary approach aims to bridge the gap between classical legal interpretations of Islam and contemporary lived Muslim realities, particularly significant for Muslims living in non-Islamic jurisdictions. Scholarship indicates Muslim women globally experience different moral conflicts in the process of self-making as they fashion pietistic selves in ways relevant to their lived experiences (Brenner 1996; Foley 2004; Keefe 2006; Simon 2009; Sahu \& Hutter 2012;). It is also not uncommon for women to report a lack of confidence in questioning the traditional interpretations of Islamic texts out of feelings of inadequacy and a general fear of deviating from what is 'Islamic' or being persecuted as a result (Olivier 2016: 279). This may be a result of the hierarchical construction of religious authority and women's continued social conditioning to undermine their own abilities, the latter of which is discussed further in the paper.

Confirming Ali's argument for an evolutionary sexual ethics, the findings of this study indicate the problematic interplay of sexuality, consent and availability in believing women's sexual choices. Understanding how these choices fit into or are further determined by concerns to maintain the peace or tranquillity of the family home make evident the complex ways in 
which pietistic sexual norms and concerns for tranquillity and peace inflect the security concerns of believing women in their homes. Through the conversations highlighted here, we gain some insights into how believing women negotiate their marital relationships to secure safe spaces from which they can fulfil their pietistic goals to observe God's will.

\section{Discussion}

I need to live in peace and harmony. I don't want all this unnecessary conflicts anymore. Even if it means if I know I am right but I have to just overlook certain things, I do that (Maymunah) ${ }^{2}$.

Continuing along these lines, the conversations that form the groundwork of this paper highlight the complex interplay of choice and obligation, as the women in this study avoid conflict and in so doing expand ideas of peacemaking through the course of being good wives and pleasing God.

Contextualising the religious environment of the women in this study, coincidentally they all participate in Ta $\mathrm{T}$ im programmes, Islamic education offered by the Tabligh Jamä'at, which includes what it means to be a good wife $^{3}$. Some women are actively involved in the facilitation of these programs and attend weekly. Others attend when convenient but are still influenced by the teachings and activities of the Tablīgh Jamä 'at which ideologies dominate in the local environment. The women spoke about the 'six points' and refer often the Fazaail-e-Aa'maal ${ }^{4}$. Influenced by ideas of Islam and piety as

${ }^{2}$ Participants were assigned pseudonyms to maintain anonymity.

${ }^{3}$ Ta $\lim$ programmes are structured weekly classes. The classes are 30 minutes long and are facilitated and attended by women only.The Tabligh Jamä 'at originated as a result of civil unrest in India and an apparent decline of Islam (Ali 2011: 230). The aim of the Tabligh Jamä'at was to renew and restore the faith of current Muslims of the time, creating better Muslims as examples to humankind and not to actively proselytize non-Muslims (Anwarul Haq 1972: 45).

${ }^{4}$ This refers to the 6 points that form the groundwork of piety in the Tablighi worldview. These include proclaiming your faith by accepting there is no God but Allah and Prophet Muhammad (peace be upon him) is the final Messenger, offering the five daily prayers, having knowledge of and remaining in the 


\section{Mariam B. Khan \& Fatima Seedat}

conceptualised by the Tabligh Jamāat, the women identified three ways in which they determined what makes a Muslim, namely, personal conduct, belief in one God and the Prophet Muhammad (peace be upon him), and pietistic practice $^{5}$. Lifestyle, defined as good conduct, dominated the discussion and it was clear amongst all participants that, in as much as ritualistic practice is crucial to their identity as Muslims, it is equally important to embody a positive character; the notion of having a 'good character' and of being 'kind, compassionate and understanding' echoed throughout the conversations with each woman. This mirrors Mahmood's argument that cultivation of piety transcends religious observance via ritualistic acts and is equally dependent on consistently seeking to conduct yourself in a manner that befits the acquisition of good deeds (Mahmood 2005: 123-4). These women called these good deeds 'aa'mals', a practice also prioritised by the Tablīgh Jamā'at (Ali 2011: 241, $245)^{6}$.

Reflecting some elements of what it means to be a good Muslim, in their understanding of the Islamic requirement of a good wife, the women prioritise two elements, namely, to serve and support one's husband and to emulate the Prophets' wives in character and conduct ${ }^{7}$. The women reported a good Muslim wife is one with whom her husband is pleased. They also

remembrance of God, maintaining respect for all Muslims (which can be extended to humankind), having good intentions and being sincere, and finally sacrificing free time in learning about religion and imparting knowledge learned (Anwarul Haq 1972: 143-47). The Fazaail-e-Aa'maal is the prescribed Tablighi text for Ta lìm programmes and a general resource (Ali 2011: 239).

${ }^{5}$ The belief in Allah as God and the subsequent belief in Muhammad (peace be upon him) as the final prophet is the universal understanding and belief amongst Muslims (Ali 2011: 231) and the participants confirm this is the generic definition and minimum requirement to identify yourself as a Muslim (Fatima 2011: 349).

${ }^{6}$ This refers to the colloquial term for 'good deeds', including but not limited to good character and good conduct. Mahmood (2005: 124) makes reference to the proper Arabic term 'al-a'mal al-saliha' which translates to good deeds.

${ }^{7}$ Muslims worldwide look to emulate figures from Islamic history as an essential component of conceptualising ideas of morality and piety (Deeb 2009: 242). 
reported being raised with ideas of a good wife as fulfilling the husband's sexual needs and being a homemaker ${ }^{8}$. The general consensus with regard to pleasing their husband revolved around sex and food ${ }^{9}$. Having just completed what is known as a one year 'survival skills course' ${ }^{10}$ which focused on Muslim women's rights, when questioned on what makes a good Muslim wife, Juwairiyah said:

In Islam it is to serve your husband. But ... a lot of culture and tradition has come into our lives. Islamically we shouldn't have to do house chores ... our husbands [are] supposed to provide everything for us. He's supposed to even give you food, have your food cooked if you can't cook and ... he's supposed to organise help for you for the kids and ... even if whatever little you have to do for your husband (referring to sexual responsiveness) you wouldn't squeal about it. If we really had our rights fulfilled as Muslim women our lives would be very different.

${ }^{8}$ This entails having regular meals prepared, the household chores complete and the children taken care of. For the purpose of this paper it is our conscious choice to focus on the sexual negotiations made by these women instead of those negotiations made with respect to homemaker responsibilities. We elaborate on this below.

${ }^{9}$ This reflects historical associations between what Al-Ghazāli calls 'the two appetites' though he argues that the desires of the stomach and the genitals in excess leads to the destruction of man (humans) and deviation from the path to God; and he subsequently suggests exercising moderation in the indulgence of both (Al-Ghazālī 1992: 21). Consequently, further research noting and comparing what the women (and their husbands) consider is excessive in terms of sexual desire and or activity would prove useful to the discourse that advances sex as an act of worship. If excess sexual desire leads to the destruction of man (humans) and deviation from the path of God, would declining one's husband's advances still be considered as not observing the will of God?

${ }^{10}$ The course the woman attended is referred to as a 'survival skills course' attended by local Muslim women to educate themselves about their Islamic rights as per the Qur'an. 


\section{Mariam B. Khan \& Fatima Seedat}

Whilst referring to homemaker duties as a pietistic requirement the women also explain it away as a cultural and not religious ideal; by challenging cultural norms they are able to regularly negotiate their positions as homemakers. Sexual availability however, which they explain is documented and emphasised repeatedly in Islamic legal texts as an obligation, we found, was less likely to be negotiated; the conditioning factor is for fear of displeasing God.

Juwairiyah's conversation reflects the difference between rights talk and obligation. She is clear that she has rights and the language of 'rights' is a recurring theme throughout the interviews. The women use rights to explain what is due to them and what is due to others from them. With respect to the rights between a husband and wife they indicate a sense of disappointment in not having their rights fulfilled and, as Juwairiyah laments above, had these rights been fulfilled she would do what she 'has to do' without 'squealing'. Juwairiyah associates her ability to happily fulfil her conjugal obligations to having her own rights fulfilled. This exchange is not unusual in marital negotiations. However, where women are expected and indeed feel compelled to maintain their obligations in the marriage without their rights being fulfilled, is our point of interest. Exploring the compromises the women make where they have knowledge of their Islamic rights, acknowledge these have not been fulfilled yet simultaneously display patience and accept their circumstances, we reflect on what Khadija learnt in the Ta lim lessons she attends, namely:

the sacrifices that the women made in Islam ... things were hard for them also ... they were satisfied with whatever little they had ... and generally being helpful to the menfolk in whichever way it was.

Despite the conviction that women have rights, finding resonance between her personal struggles and those of the early days of Islam, Khadija takes the women of the past as role models and therefore reasons that being a good Muslim women includes 'sacrifice', being 'satisfied with little' and 'being helpful to the menfolk in whichever way'. Her comment also reveals the influence the Ta ' lim programmes have on these women, though it is important to note that this form of indoctrination is not limited to the Tabligh Jama ${ }^{\prime} a t^{11}$.

${ }^{11}$ See Hoel and Shaikh (2013:80) where women in their Cape Town study are schooled in madrassah's and marriage classes to refrain from turning down 
Overt about the significance of pleasing your husband, Khadija said:

To please your husband is to please Allah and the curse is on a woman who is disobedient to her husband. And we read the hadith', we go for Ta 'im, the hadith' are all authentic hadith. So the hadith that we are reading, it's a lesson for us.

Khadija's reference here is to a commonly cited hadith, which brings a night full of curses (from the angels) upon a woman who does not respond to her husband's sexual approach ${ }^{12}$. The ahadith she refers to of the Ta'inm programmes appear to lend themselves to an interpretation which ensures that good wives are women who please their husbands, reinforcing essentialist gender roles. In their desire to please their husbands (thereby earning God's favour) most of the women feel compelled to meet their husband's requirements, regardless of their own desires.

Elaborating on the significance of pleasing her husband Zaynab said:

I think it's very important, especially in the bedroom (giggle) that's basically what our husbands need ... I think that their perspective of it ... Islamically it's not allowed (to say no). You should give it to him whether you're happy or not because at the end of the day he's gonna (sic) be happy with you and you gonna (sic) have a happy relationship .... I'm talking from my point of view because I know if I say no all the time, he becomes aggressive. He becomes angry. So, probably we just have to give in, whether we like it or not, just give in.

For Zaynab, sexual responsiveness in the absence of sexual desire is informed

their husband's sexual advances. The findings of this study regarding the understanding of Islamic teachings with respect to sexual access is supported by Hoel and Shaikh (2013) in their study of South African Muslim women.

${ }^{12}$ See for example, Al-Bukhārī ([1979] 1986) Chapter 86 reads as follows: 'If a woman spends the night deserting her husband's bed (without a reasonable cause) she is sinful'. Variant endings present as: ' $\ldots$ the angels send their curses on her till morning'; '... the angels send their curses on her till she comes back (to her husband)'( (trans.) Al-Hilali and Khan, Volume V11, p. 93). 


\section{Mariam B. Khan \& Fatima Seedat}

by the greater desire to maintain a 'happy relationship' or in other words she ensures a peaceful environment by avoiding conflict. Zaynab makes a choice to sacrifice her own 'happiness' by prioritising her husbands, which entails giving her husband what he 'needs'. Her approach is not unusual. Similarly, in a Ugandan study, a participant reported 'her ambivalence about having sex when she did not want it mixed with feelings of guilt about rejecting her husband' (Cash 2011: 33). In that study the need to cultivate inner peace through the dynamics of her relationship with her partner motivated her rationalisations between consensual or negotiated sex and forced sex, which she further differentiated from rape by reminding herself that the coercive party is her spouse and not a stranger (Cash 2011: 30).

Khadija's understanding of sexual availability as obligatory (it is not allowed to say no) reflects a complex interplay of choice and obligation in her path to God:

Sometimes I'm not in the mood, honestly. But he'll [quote] the hadith ... That's the rights of the husband over the wife.

Whilst her husband may not be demanding sexual access through a physical threat, his approach uses a religious teaching as a form of intimidation and emotional threat. Khadija's husband plays upon her pietistic aspirations and through the hadith he reminds her that not meeting his sexual need threatens her own spirituality. Other research has conceptualised this threat in psychological terms ${ }^{13}$. In addition, may we also read this in spiritual terms as a spiritual threat? Khadija's husband's reminder is intended to place Khadija's sexuality to the background and to bring her piety into focus. The effect is to make Khadija's piety dependant on sublimating her sexuality, and thus achieve the pietistic goal of pleasing her husband, and her goal of living 'Islamically'. On engaging in sexual intimacy despite lack of personal interest, Khadija said:

If I say no, he becomes aggressive, angry. It's just gonna ( unnecessary problems, it's just gonna ( $\mathrm{sic}$ ) make everybody miserable ... it's not a happy environment so [we] probably just have to give in, whether we like it or not. Not everyone is like this ... That's the way I

${ }^{13}$ Hoel and Shaikh (2013: 76-77) note the 'psychological pressure on women to be sexually responsive'. 
am ... Maybe because I'm not brave enough ... I'm fine with the way I am. It doesn't really affect me [to the point] where my marriage is such a problem that I can't live in my marriage. It's like more an acceptance now. That's part of my life. I can sing and knock my head, what I want is not gonna (sic) happen so [I] might as well just get over with it. And shukr [thankfully], I manage. It's not like I can't manage at all or it's hampering me or my health in any way.

Khadija's 'acceptance' is informed by her desire to avoid conflict thereby maintaining a peaceful or a 'happy environment'. Her reasons for acquiescing include avoiding misery and avoiding angering her husband, as she explains, she is 'not brave enough' to do otherwise.

Her argument that it does not affect her health begs the question: if she considered her health to be at risk, would she leave? Whether she is referring to physical or mental/emotional health, sexuality is a major determinant of women's mental health (Kadri, Berrada, McHichi Alami, Manoudi, Rachidi, Maftouh \& Halbreich 2007: 199). Furthermore, mental health is impacted by gender related differences (World Health Organisation 1998: 6; Douki, Zineb, Nacef \& Halbreich 2007: 178). Referring to the consistent barrage of patriarchal messages that lead women to question their capacity to function as individuals, Walters argues that not only does sexuality influence the manner in which women perceive themselves and other women, it also affects a women's psychological and intellectual health (Walters 1990: 17-18).

On the ethics of consent and obligation in terms of the connections between women's sexuality and mental health, alongside other studies on the diverse factors affecting sexuality, this confirms the call for a multidisciplinary approach to women's healthcare (Kadri et al. 2007: 199). As an example, oral contraceptives may produce negative effects such as changes in mood and libido and even vaginal dryness in some women (Gibbon 2005: 220). Any one or all of these side effects may result in a woman declining her husband's advances. A woman who is unaware of the possible side effects of oral contraception may also be unaware that her decrease in libido has a pharmacological aetiology. A further finding of this study indicated that at some point in their marriages, mostly in the early years when many couples are often more sexually active, the women all used oral contraception. Connecting the impulse to acquiesce to a husbands sexual needs, the moral sanction or that it is considered 'Islamically' unacceptable to say no, and the pharmacological 


\section{Mariam B. Khan \& Fatima Seedat}

impacts of oral contraception on libido and genital physiology, makes evident a rather complex association of factors at play in women's sexual negotiations. Under these circumstances, what might be considered a legitimate reason for saying no?

Remaining sexually available to their husband was one of the ways in which women maintained peace. The second way in which this happened was by accepting that their husbands have the prerogative to affect their lives in ways with which they may not agree. At the heart of all these negotiations lies their pietistic concern to observe God's will and their desire to achieve Heaven. Women explained their acquiescence when faced with the threat of polygyny ${ }^{14}$. As Aisha explains:

I mean if my husband decides to have another wife I can't stop him because that's the right, that's his right and that's what God said, that you can have up to four wives but you have to use your discretion, you have to like treat all of them equally... because I am a Muslim ... whatever my Allah says ... I mean if you ask any woman 'would you be happy if your husband takes another wife?' She'll say 'No, definitely not', but because my Allah has dictated that I will not go against that. If that's what my husband wants I'll say 'yes, God says you can. It's allowed in the religion'. And I feel in that way instead of having these extra marital affairs that are going out in the West it'll save us from so much of all those diseases being brought home you know. So there are four wives or whatever, you know you're doing your thing and it's just these four wives you know and if God allows it why not?

Aisha tries to rationalise the idea of polygyny whilst having personal conflicts about possibly 'sharing' her husband with three other women. She accepts the possibility of a polygynous marriage because she accepts that it has religious sanction. Her choice to be submissive to this possibility arises from a fear of infidelity which may be quite damaging to the psychological wellbeing of an individual, woman or man, as it triggers feelings of personal inadequacy to meet the needs of the opposite partner (Cash 2011: 31-32). She also comforts

${ }^{14}$ See for example Khan (2016: 3-4) where this is a serious concern in Egypt and Nigeria. 
herself by saying it is a protective measure from sexually transmitted diseases but reveals her bias when she limits sexually transmitted disease to the West. Evidently, Aisha is aware that her status of only wife is precarious; she may be joined at any time by other wives.

Vulnerability created by, amongst other factors, a lack of financial independence, the threat of polygyny and religious socialization that promotes wives in the role of service and support to their husbands, suggests that Muslim wives may be relinquishing their sexual agency by choosing to 'overlook certain things', whilst remaining convinced of their own decisions. Recalling Maymunah's earlier words sums up a number of women's responses to the choice between conflict and peace:

At that young age I went through so much. Now I am mature. I am at this age where there should be things for myself and I need that peace at home because I need to live in peace and harmony. I don't want all this unnecessary conflicts anymore. Even if it means if I know I am right but I have to just overlook certain things, I do that.

Overlooking what she knows to be wrong, does not detract from Maymunah's knowledge that she is right. It can be read as exercising a different form of agency, one that avoids conflict and prioritises 'peace and harmony'. The conversations indicated that care for maintaining peace in the home played a significant role in determining these choices.

Alongside the desire for peace and harmony in their homes, a pervasive theme through all interviews was the desire to achieve Heaven. Heaven in the afterlife is a pietistic aspiration that is not equated to the desire for death but is the motivating factor to acquire more good deeds (Deeb 2009: 251).

The pietistic aspiration of acquiring Heaven is reflected in Khadija's statement:

Successful is the person who gains entry into Jannah and [the] only way you can see this is to do the right things. If a husband is pleased with his wife when she dies, she goes direct to Jannah. Who doesn't want that? ... One time he was very pleased with me and he said 'I'm happy with you' and he thanked me. I said, 'I can die because you [are] pleased with me, I can die now. That's what I live for, is for the 


\section{Aakhirah ${ }^{15}$.}

Her emphasis is on the need to do that which is right and she links doing what is right with pleasing her husband. Her excitement at the possibility of achieving her goal in the hereafter originates in her belief that her husband's happiness also ensures her access to her goal.

If a good wife is one who does that which is right by meeting all of her husband's sexual needs, would a good husband then be one who prioritises the need for peace and tranquillity in the home over the need for sexual gratification every time he is aroused? Hafsah's comment below explains who she considers a good man:

To be a good Muslim wife ... there's these conditions that if you abide to, then you are guaranteed Heaven... I read it all the time ... I think if a man expects you to be intimate when you're upset, he's not much of a man.

Hafsah acknowledges that her sexuality is conditioned by her husband's needs, but also argues against a form of masculinity that presumes male sexual entitlement.

The idea that 'sex is a need which has to be satisfied' encourages a sense of male entitlement and the idea that men are 'not able to abstain from sexual activity' (Kadri et al. 2007: 200-201). The inferences that can be drawn from this are that men's behaviours are involuntary, they have no control over their desires and every sexual urge must manifest in penetrative sexual gratification.

Popular teachings that stipulate extra-marital sex as a great sin, accompanied by cultural understandings of male sexuality as rampant or uncontrollable, may validate the use of coercion in sexual relations; husbands may claim it prevents them from sinning outside the marriage. This is contrary to the ideas of 'common good and human welfare' which scholars apply in understanding the objectives of Islamic law (Masud 2013: 37). This also allows men to abdicate responsibility for their sexual control and place the responsibility of men's morality on the conscience of women.

${ }^{15}$ Aakhirah refers to the Hereafter or the afterlife and in this context is specific to Heaven. 
Contemporary Muslim authorities also cite historical legal sources to maintain a differential understanding of male and female sexuality based on what they analyse as 'the inherent temperamental, physical and emotional differences between the sexes' (al-Kawthari 2008: 13) ${ }^{16}$ These differences match the legal differences between husbands and wives, as al-Kawthari's explains, while a 'husband can demand sex' and 'the wife must consent', unless she has a 'genuine physical excuse of Sharīa-countenanced impediment', the wife cannot make a similar demand if the couple has had sex 'at least once since being married' (al-Kawthari 2008: 13). Nonetheless,

a man is entitled to have sex with his wife whenever he is desirous of it and it is her religious duty to make herself available to him. Failing to do so without a valid excuse is a major sin, and this is emphasised in many hadiths (al-Kawthari 2008: 13)

The hadith that follows al-Kawthari's analysis is the same hadith the women refer to in their conversations (see note 14), where angels curse the woman who refuses her husbands bed. However, al-Kawthari also explains that while the law may be clear, 'seeking one's rights through demands, force and argumentation contradicts the spirit of marriage', accordingly, marital rights must be understood against other hadith that prioritise good character with one's spouse (al-Kawthari 2008: 13).

This is not an unusual sentiment amongst religious scholars. In an Indonesian study, a religious scholar is quoted to have said, 'submission is not appropriate in all circumstances, especially in things that go against religion' (Aisyah \& Parker 2014: 212). Aisyah and Parker interpret this to indicate that 'men do not have absolute rights or power over women' thereby negating the need for unconditional submission (Aisyah \& Parker 2014: 212). In support of this view, Shaikh ibn Uthaimin's fatwa ${ }^{17}$ regarding the sinfulness of a woman who does not prioritise her husband's sexual access is as follows:

${ }^{16}$ Al-Kawthari (2008: 13) relies here on Ibn Abidin's (d. 1252/1836) Radd alMuhtär which is a commentary on Aala-al-Din's al-Haskafi's (d. 1070/1660) Durr al-Mukhtār, namely 3:4.

${ }^{17}$ A fatwa is a response from a qualified Muslim jurist, to a legal question (Brockopp 2008: 5). In this case the jurist is a Member of the Senior Scholars Committee of the Kingdom of Saudi Arabia. 
It is obligatory upon the wife to respond to her husband if he calls her to his bed. However, if she is psychologically ill and is not able to actively respond to his call or if she has a physical illness, then in such cases it is not allowed for the husband to call upon her. This is because the Prophet (peace be upon him) said, 'There is to be no harm done or reciprocation of harm' ${ }^{18}$

He should either refrain or enjoy her company in such a way that does not harm her (Al-Musnad 1996: 220).

The above fatwa while confirming the tradition that obligates women to sexual availability allows for a nuanced reading of the hadith. In the context of moral consciousness and the presumed tranquil domain of marriage, it demands men condition the dominant 'male right and female duty' discourse of sexuality that pervades Islamic legal texts (Ali 2006: 13). It also emphasises the psychological wellbeing of a believer whose health must be considered in holistic terms. Ideally this is a rather progressive approach. However, we are reminded of the stigma attached to people with diagnosed or suspected mental illness (Corrigan 2004: 614). Diagnosis or identification of psychological strain of any aetiology may actually be problematic for women. It would not only render more women ineffective as a result of emotional or psychological weakness or instability but it would also increase vulnerability by opening spaces for the much dreaded polygyny. However, the fatwa's reference to nonharmful ways of enjoying a wife's company opens the possibility for an approach to sex and sexuality discourse that is more inclusive of other, meaning non-penetrative, means of sexual gratification.

Both al-Kawthari and ibn Uthaimin produce an analysis that straddles the spaces between law and ethics. Al-Kawthari refers to 'the spirit of marriage' and ibn Uthaimin's caution against doing harm draws on the legal $\operatorname{maxim}^{19}$ 'there is to be no harm done or reciprocation of harm'. This legal maxim is part of a broader list of maxims that guide the production and application of Islamic law, amongst them the consensus on the objectives of Islamic jurisprudence, interpreted through ideas of 'common good and human

${ }^{18}$ Recorded by Ahmad, Malik and ibn Majah. Al-Albani has graded it Sahih, (Sahih al-Jami Volume 2: 1249).

${ }^{19}$ For example, see the book of 'Legal Maxims of Islamic Jurisprudence' that is studied at the Islamic University of North America (Mishkah 2013). 
welfare' (Masud 2013: 37). Between al-Kawthari and ibn Uthaimin, there is a suggestion that there may be room to explore an ethics of sexuality that is inclusive of the spirit of marriage and the avoidance of harm. For the interests of the women in this study, to what degree can this approach override the approach they currently use; to what extent can women call on the spirit of marriage and the avoidance of harm to say no to sex when they are not desirous?

The women speak in an idiom of piety in the path of Allah (Ali 2011: 226) for Muslims generally so as to include 'good character, kindness and compassion'. In a marital relationship, the character of a good wife also includes 'good character, kindness and compassion' but our analysis indicates that this is further measured by their readiness to be sexually available. While it may be that a good man does not demand sex when his wife is upset, it appears that a good wife also does not refuse a husband only because she has no similar desire at the time.

While some feminist scholarship has dismissed women's pietistic efforts as involuntary and puppeteered by patriarchal teachings or androcentric religious contexts which strip them of agency, others have argued that the global increase in models of pietistic femininity through the 'conscious and deliberate' choice to adhere to the tenets of Islam, has the potential to subvert discourses centred on a binary of subservience and resistance (Mahmood 2005; Tong \& Turner 2008: 43; Jacobsen 2011: 66; Rozario 2011: 285;). Mahmood's agential interpretation of the same revivalism also offers an alternative reading of the pietistic motivations that inform the sexual negotiations of Muslim wives concerned with pleasing their husbands, maintaining a peaceful home and the final goal of securing a place in Heaven.

Our analysis indicates that peace in the home and, more so, personal peace of mind is paramount to the women in this study. Our concern though remains in the maintenance of the status quo through such forms of agency. What are the broader implications of avoiding conflict by suppressing their dissatisfaction? The gendered power relations entailed in being a stay-at-home wife produce financial vulnerability and dependence to the extent that to remain in such situations may be the only choice. Given how expressive agency is not an uncommon trigger for domestic violence (Aisyah \& Parker 2014: 206), the added fear for physical manifestations of aggression may also be what prompts women to avoid the conflict of verbal negotiation in certain cercumstance? 
Despite personal beliefs otherwise, the women accept it is their obligation to please their husbands and this allows them to also please God. Whether they see it taking a toll on them physically, mentally and emotionally, they see it as compromise or the fulfilment of an obligation, it is a means of cultivating themselves to exercise virtues such as patience, and in the process becoming better Muslims. This is in keeping with Mahmood's analysis of pietistic self-formation in the women's mosque movement in Egypt (Mahmood 2005). Mahmood's analysis challenges our understanding of pietistic agency illustrating how women use their piety for self-making and autonomy (Mahmood 2005: 175), which our analysis verifies; here agency manifests in upholding expected religious norms (Aslam 2010: 422-423). In this pietistic context, it would be apt to define agency thus:

not as the freedom to do what she wanted but the freedom to do what was right, where what was right for her was the voice of God (Mack 2003 cited in Aslam 2010: 422-23).

The sexual choices of Muslim wives in this study make us aware of the operations of the agency of women who submit to sex irrespective of desire, as a measure of their faith and a means of cultivating piety. With the intricate connections between sexuality and women's mental health, what are the implications of submitting to a husband's needs at the expense of one's personal desires or lack thereof? Reasonable cause, as is evident in the fatwa above, includes mental health. Considering medical textbook records of the multitude of factors that affect libido (Beers, Porter, Jones, Kaplan \& Berkwits 2006: 2099), possible further study would be to understand what these women consider to be valid reasons to say no.

Further, can sexual sublimation with potential impact on physical, emotional, and psychological health of a believing woman be considered an act of piety? Contextualising Aisyah and Parker's (2014: 212) argument for resistance to acts of violence, if sexual coercion through spiritual threat was to be considered an act that violates the peaceful ethos of an Islamic home and the peace-building nature of Islamic teachings, could 'resistant' agency in this context be understood as upholding expected religious norms and hence, also a form of piety?

Reflecting the interplay of choice and obligation, Juwairiyah said: 
Like everything we do in our religion ... certain things are compulsory, but it's your choice too ... It's left to the individual.

She suggests that, whilst sexual engagement in marriage may be considered an obligation, it is not one that comes without the possibility of choice. The women in this study are clearly making choices; they choose between the value and costs of sexual intimacy when they are not desirous, a night without cursing angels, a husband that is sexually satisfied and a home that feels peaceful, an opportunity to please or displease God and the possibility of obtaining Heaven. Their conversations indicate the ways in which these choices function to affect their pietistic interests as believing individuals.

Drawing on an ethics that would maintain the 'spirit of marriage' and 'avoid doing harm' and in response to Kecia Ali's call for a more 'just ethics of sexual intimacy', one that incorporates 'meaningful consent and mutuality' (Ali 2006: 151), the findings of this study reinforce the need for an expanded approach to Muslim women's sexual agency; one that is inclusive of, considerations of mental health, at times non-penetrative forms of sexual gratification, and ideas of peace-making and conflict resolution that include discussions and choice around what entails sexual gratification, how frequently it is enjoyed in the marriage and what is a reasonable cause to say no.

\section{Conclusion}

In the analysis above we observe that these South African Muslim women's lives reflect a complex interplay of choice and obligation in their path to God. We can infer that these women perceive a successful marriage, in terms of tranquility and peace between partners, as an equally important measure of their faith. Further, conflict in marriage is not anomalous, and therefore pious women who intend to maintain a conflict free or peaceful marriage strategise toward this goal. Viewed through the lens of piety, the narratives that explain their negotiations make consistent reference to the 'rights of others', the care they take to avoid 'hurting someone', their efforts to acquire 'good deeds' and to display 'good morals'. As a result they frequently sublimate their desires either in the interests of a delayed heavenly reward, the interests of their husband's desires or the interests of their pietistic tradition, Islam.

Preferring heavenly rewards over earthy ones, the result is an ethics of 


\section{Mariam B. Khan \& Fatima Seedat}

domestic peace-making that prioritises peaceful coexistence, conceptualised as a state of conformity and sublimation, despite one's lack of sexual desire. The needs and interests of the tradition, the family and the husband take priority, but only because they also feed the pietistic goals of the believing woman. ${ }^{20}$ In this way, they give form to the ethical voices of their Islamic teachings, and at times this is at the expense of what they want or what they 'know is right'. Their practices make evident Leila Ahmed's (1992) observations on the ethical voice of Islam, which in the context of marriage is stronger for women, in contrast to the legal voice, which appeals to men. This pietistic ethic is not based on reciprocity, but on a negotiated concession which requires a woman to make herself sexually available despite having no sexual desire but for the guarantee of pleasing God.

In conclusion, this paper makes evident the connections between domestic security or peace-making and sexual choice, and subsequently the ethical concerns produced in this connection. Moving forward, the observations gathered here may be factored into Ali's call for 'a more viable and equitable ethics of sex' (Ali 2006: 72). They also support Hoel and Shaikh who acknowledge women's 'moral agency and personhood', which would necessarily play a central role in the formulation of this new ethics (Hoel \& Shaikh 2013: 91). The findings of this study suggest that women's interests in maintaining a peaceful marriage and guarding their domestic security may be as significant in this review. Efforts to formulate a new sexual ethics will need to account for historical sexual norms that associate piety and tranquillity in the home with sexual subjugation. The angels that curse a woman who denies her husband's sexual advances threaten a peaceful home; how do we understand pietistic sexual ethics of a woman who chooses undesirable sex over undesirable curses?

\section{References}

Ahmed, L. 1992. Women and Gender in Islam. New Haven \& London: Yale University Press.

${ }^{20}$ Considering the women's elaborate efforts for peace and domestic security alongside a fervent desire to strive for Heaven, a parallel study gauging men's understandings of the pietistic requirements to observe God's may prove valuable. 
Aisyah, S. \& L. Parker 2014. Problematic Conjugations: Women's Agency, Marriage and Domestic Violence in Indonesia. Asian Studies Review 38,2: 205-223.

Al-Bukhārī, Muhammad ibn Ismā'îl [1979] 1986. The Book of Nikah. AlHilali, M.T. \& M.M. Khan (trans.). Lahore: Kazi Publications.

Al-Ghazālī, A.H. 1992. Abstinence in Islam: Kasr al Shahwatayn (Curbing the Two Appetites) from Ihyà' 'ulüm al-dīn (Revivification of the Sciences of Religion). Farah, C.E. (trans.). Available at: http://ghazali.org/works/ astin.htm. (Accessed on 15 December 2015.)

Ali, J.A. 2011. Piety among Tablīghī Women. Contemporary Islam 5: 225247.

Ali, K. 2006. Sexual Ethics \& Islam: Feminist Reflections on Qur'an, Hadith, and Jurisprudence. London: Oneworld Publications.

Al-Kawthari, Muhammad Ibn Adam 2008. Islamic Guide to Sexual Relations. London: Huma Press.

Al-Musnad, Muhammad bin Abdul-Aziz 1996. Islamic Fatawa Regarding Women. Zarabozo, J.A. (trans.). Riyadh: Darussalam.

Anwarul Haq, M. 1972. The Faith Movement of Mawlana Muhammad Ilyas. London: George Allen and Unwin Ltd

Aslam, M. 2010. 'New Vulnerabilities' of Muslim Women in the Age of Terror: The Case of the Red Mosque Siege in Islamabad, Pakistan. Totalitarian Movements and Political Religions 11,3-4: 417-434.

Bahar, Z., H. Okcay, S. Ozbicakc1, A. Beser, B. Ustun \& M. Ozturk 2005. The Effects of Islam and Traditional Practices on Women's Health and Reproduction. Nursing Ethics 12,6: 557-570.

Beers, M.H., R.S. Porter, T.V. Jones, J.L. Kaplan \& M. Berkwitts [1989] 2006. The Merck Manual of Diagnosis and Therapy. $18^{\text {th }}$ Edition. New Jersey: Merck Research Libraries.

Boonzaier, F. 2005. Woman Abuse in South Africa: A Brief Contextual Analysis. Feminism and Psychology 15,1: 99-103.

Bowen, D.L. 1981. Muslim Juridical Opinions Concerning the Status of Women as Demonstrated by the Case of `azl. Journal of Near Eastern Studies 40,4: 323-328.

Brenner, S. 1996. Reconstructing Self and Society: Javanese Muslim Women and 'The Veil'. American Ethnologist 23,4: 673-697.

Brockopp, J.E. 2008. Islam and Bioethics: Beyond Abortion and Euthenasia. Journal of Religious Ethics 36,1: 3-12. 
Cash, K. 2011. What's Shame Got to Do With It: Forced Sex among Married or Steady Partners in Uganda. African Journal of Reproductive Health 15,3: 25-40.

Christopher, E. 2006. Religious Aspects of Contraception. Reviews in Gynaecological and Perinatal Practice 6: 192-198.

Corrigan, P. 2004. How Stigma Interferes with Mental Health Care. American Psychologist 59,7: 614-625.

Deeb, L. 2009. Emulating and/or Embodying the Ideal: The Gendering of Temporal Frameworks and Islamic Role Models in Shi i Lebanon. American Ethnologist 36,2: 242-257.

Dhami, S. \& A. Sheikh 2000. The Muslim Family: Predicament and Promise. The Western Journal of Medicine 173: 352-356.

Douki, S., S. Ben Zineb, F. Nacef \& U. Halbreich 2007. Women's Mental Health in the Muslim World: Cultural, Religious and Social Issues. Journal of Affective Disorders 102: 177-189.

Foley, R. 2004. Muslim Women's Challenges to Islamic Law: The Case of Malaysia. International Feminist Journal of Politics 6,1: 53-84.

Fatima, S. 2011. Who Counts as a Muslim? Identity, Multiplicity and Politics. Journal of Muslim Minority Affairs 31,3: 339-353.

Gibbon, C.J. 2005 [1988]. South African Medicines Formulary. $7^{\text {th }}$ Edition. Cape Town: Health and Medical Publishing Group of the South African Medical Association.

Hoel, N. \& S. Shaikh 2013. Sex as Ibadah: Religion, Gender and Subjectivity among South African Muslim Women. Journal of Feminist Studies in Religion 29, 1: 69-91.

Huq, S. \& S.F. Rashid 2008. Refashioning Islam: Elite Women and Piety in Bangladesh. Contemporary Islam 2: 7-22.

Jacobsen, C.M. 2011. Troublesome Threesome: Feminism, Anthropology and Muslim Women's Piety. Feminist Review 98: 65-82.

Kadri, N., S. Berrada, K. McHichi Alami, F. Manoudi, L. Rachidi, S. Maftouh \& U. Halbreich 2007. Mental Health of Moroccan Women: A Sexual Perspective. Journal of Affective Disorders 102: 199-207.

Keefe, S.K. 2006. 'Women do what they want': Islam and Permanent Contraception in Northern Tanzania. Social Science \& Medicine 63: 418429.

Khan, M.B. 2015. Negotiating between Health-based Contraceptive Concerns and Piety: The Experiences of Muslim Wives in the Greater Durban Area. 
Unpublished Master's Dissertation: University of KwaZulu-Natal.

Khan, M.B. 2016. How Religious Extremism Compromises Women's Security, Agency and Mental Health: Conversation with Sarah Eltantawi. Agenda 30,3: 1-7.

Lazarus, A. \& C. Taylor 1999. Women and Peacebuilding. Agenda 15,40: 9194.

Lewis, D. 2013. The Multiple Dimensions of Human Security through the Lens of African Feminist Intellectual Activism. Africa Peace and Conflict Journal 6,1: 15-28.

Mahmood, S. 2005. Politics of Piety: The Islamic Revival and the Feminist Subject. Princeton: Princeton University Press.

Masud, K.M. 2013. Shari'a Today: Essays on Contemporary Issues and Debates in Muslim Societies. Islamabad: Iqbal International Institute for Research and Dialogue, and National Book Foundation.

Olivier, B. 2016. The Malaysian Islamization Phenomenon: The Underlying Dynamics and their Impact on Muslim Women. Islam and ChristianMuslim Relations 27,3: 267-282.

Omran, A.R. 1992. Family Planning in the Legacy of Islam. London: Routledge.

Patton, M.Q. [1990] 2002. Qualitative Research and Evaluation Methods. $3^{\text {rd }}$ Edition. Thousand Oaks: Sage Publications.

Pera, S.A. \& S. van Tonder [1996] 2005. Ethics in Healthcare. Landsdowne: Juta \& Co.

Peterson, E. 2016. Working with Religious Leaders and Faith Communities to Advance Culturally Informed Strategies to Address Violence against Women. Agenda 30,3: 50-59.

Rozario, S. 2011. Islamic Piety against the Family: From 'Traditional' to 'Pure' Islam. Contemporary Islam 5: 285-308.

Sahu, B. \& I. Hutter 2012. 'Lived Islam' in India and Bangladesh: Negotiating Religion to Realise Reproductive Aspirations. Culture, Health \& Sexuality 14,5: 521-535.

Seedat, F. 2016. Women, Religion and Security. Agenda 30,3: 3-10.

Shaikh, S. 2003. Family Planning, Contraception and Abortion in Islam: Undertaking Khilafah. In Maguire, D.C. (ed.) Sacred Rights: The Case for Contraception and Abortion in World Religions. Oxford: University Press.

Simon, G.M. 2009. The Soul Freed of Cares? Islamic Prayer, Subjectivity, and 
the Contradictions of Moral Selfhood in Minangkabau, Indonesia. American Ethnologist 36,2: 258-275.

Sjoberg, L. \& J. Martin. 2007. Feminist Security Studies: Conversations and Introductions. ISA Compendium Project 50-59.

Srikanthan, A. \& R.L. Reid 2008. Religious and Cultural Influences on Contraception. Journal of Obstetrics and Gynecology (Canada) 129-137. Tong, J.K. \& B.S. Turner 2008. Women, Piety and Practice: A Study of Women and Religious Practice in Malaysia. Contemporary Islam: Dynamics of Muslim Life 2,38: 41-59.

Walters, M. 1990. A Feminist Perspective in Family Therapy. In Perelberg, R.J. \& A.C. Miller (eds.): Gender and Power in Families. London: Routledge.

World Health Organisation 1998. The World Health Report. Executive Summary. Geneva: WHO. Available at: http://www.who.int/whr/1998 /en. (Accessed on 8 January 2016).

Mariam B. Khan Doctor of Natural Medicine and Practitioner of DNAlysis Biotechnology University of KwaZulu-Natal dr.mariam.b.khan@gmail.com

Fatima Seedat

Gender Studies University of Cape Town fatima.seedat@uct.ac.za 